\title{
Olinia chimanimani (Penaeaceae), a new species endemic to the Chimanimani Mountains of Mozambique and Zimbabwe
}

\author{
Toral Shah $^{1}$ (D), lain Darbyshire ${ }^{1} \&$ Hermenegildo Matimele ${ }^{2}$
}

Summary. Olinia chimanimani T. Shah \& I. Darbysh. is described as a distinct species from the Chimanimani mountains in Mozambique and Zimbabwe, based on morphological evidence. It differs from other species of Olinia sect. Rochetiana in its smaller leaf size, sessile leaf attachment, glabrous flowers and galled flowers becoming narrowly swollen without prominent tubercles when infected. A species description, key and illustration, distribution map and ecological information are provided. The populations have been studied in the field, and it is only known from two locations. It is potentially under threat from burning due to human activity associated with illegal artisanal mining activity, and thus has been evaluated as Endangered (EN) using the IUCN Red List categories and criteria.

Key Words. conservation, Endangered, IUCN Red List assessment, key, morphology, Oliniaceae, restricted range.

\section{Introduction}

The Chimanimani - Nyanga Highlands in Southeast Africa are the most isolated component of the African Great Escarpment (Clark et al. 2011) and are noted for their significantly high levels of endemism (Wild 1964). The Chimanimani Mountain range is situated on the border of Zimbabwe and Mozambique (approx. 33 $00 \mathrm{E}$, $19^{\circ} 50 \mathrm{~S}$ ) and forms part of the Eastern Afromontane hotspot (BirdLife International 2012). Its relative isolation from other mountains and an unusual underlying geology, with extensive outcrops of nutrient-poor quartzite, have given rise to a biodiversity hotspot with high plant endemism.

The region has been of long-standing interest for botanists, with the majority of information and plant collections derived from the Zimbabwe portion whilst the larger Mozambican side of the massif has been far less well studied. Recent surveys under a Critical Ecosystem Partnership Fund (CEPF) project "In from the cold: providing the knowledge base for comprehensive biodiversity conservation in the Chimanimani Mountains, Mozambique" have addressed this gap by facilitating a botanical study of the Mozambique side, resulting in a better understanding of the endemic species, their distribution, threats and conservation status (Timberlake et al. 2016). This work has resulted in a comprehensive checklist of species with a restricted distribution occurring on quartzite and scrub above $1200 \mathrm{~m}$, with 74 strict endemic and 19 nearendemic taxa documented (Wursten et al. 2017). These recent surveys have also uncovered several potentially new species to science, as well as providing more collections for species that had previously only been considered to be tentatively distinct and not formally described, such as Empogona jenniferae Cheek (Cheek et al. in press). The number of endemic plant species on Chimanimani is therefore sure to continue to rise.

The most recent taxonomic revision of the genus Olinia Thunb. was carried out by Sebola \& Balkwill (2013) supported by a phenetic analysis (Sebola \& Balkwill 2009). They recognised ten species divided into two sections; sect. Olinia and sect. Rochetiana, readily separated by their morphology. Sect. Olinia has inconspicuous tertiary veins on the adaxial surface with tertiary veins looping only once at the margin and sect. Rochetiana, has conspicuous tertiary venation on the adaxial surface with tertiary veins looping twice at the margin (Sebola \& Balkwill 2013). Olinia has previously been placed in its own monogeneric family, Oliniaceae (see e.g. Verdcourt 1978; Heywood et al. 2007). However, it has recently been transferred to the Penaeaceae family based on molecular evidence, where it is recognised as one of three tribes, Olinieae Horan. alongside Rhynchocalyceae Beusekom and Penaeeae DC. (APG IV 2016).

During the first of three CEPF surveys in 2014, two collections of an unusually small-leaved species of Olinia were made by the third author of this paper on the Mozambican side of Chimanimani. These specimens were matched to existing specimens from the Chimanimani Mountains in the Kew (K) herbarium. The first ever collection of this small-leaved Olinia was made by Hiram Wild (Wild 3606) in 1950 on the Zimbabwe side of the

\footnotetext{
Accepted for publication 23 May 2018. Published online 25 July 2018

1 Herbarium, Library, Art \& Archives, Royal Botanic Gardens, Kew, Richmond, Surrey, TW9 3AE, UK. e-mail: t.shah@kew.org

2 Instituto de Investigacão Agrária de Mocambique, IIAM, Maputo, Mozambique.
} 
massif. This specimen, and the later collection Whellan 2203 (K), were recognised by Verdcourt (1978) in the Flora Zambesiaca treatment of Oliniaceae as a pathological form of Olinia vanguerioides Baker $\mathrm{f}$., but he noted that the specimens had much smaller leaves. Sebola \& Balkwill (2013) did not discuss or cite these collections, or a third, flowering specimen Linder 3990 (K) within any of their delimited species. A further botanical expedition to the Chimanimani Mountains in 2016, during which this Olinia species was specifically targeted, resulted in additional collections with similar characteristics growing in similar habitats to the older specimens. All the specimens are restricted to higher elevation regions of Chimanimani. These specimens were closely compared with sympatric and morphologically similar species of Olinia in order to assess its taxonomic status and it is concluded that the Chimanimani taxon is a distinct species, described here as Olinia chimanimani $\mathrm{T}$. Shah \& I. Darbysh.

Further, it was brought to light during this study, that whilst Sebola and Balkwill (2013) recognised two sections in Olinia, these were not validated according to Article 40.1 of the Botanical Code (ICN, McNeill et al. 2012). To rectify this, we validate sect. Rochetiana in the taxonomic treatment below.

\section{Material and Methods}

Morphological characters for the new species were measured on herbarium specimens at the Kew herbarium. Other herbaria with holdings of Zimbabwean and Mozambican specimens (BM, LMA, SRGH) were checked for additional material of the new species, but none were found. All characters were measured on dry material, except internal floral characters which were measured from a rehydrated flower under a dissecting microscope. Characters deemed to be of taxonomic significance follow the most recent monographic revision of Olinia (Sebola \& Balkwill 2013) and the terminology is according to Beentje (2010). A species conservation assessment was made using the categories and criteria of IUCN (2012).

\section{Taxonomic Treatment}

Olinia sect. Rochetiana Sebola E Balkwill ex T. Shah sect. nov. Type species: Olinia rochetiana A. Juss., Comp. Rend. Hebd. Séances Acad. Sci. 22: 812 (Jussieu 1846).

http://www.ipni.org/urn:lsid:ipni.org:names:77178774-1

Olinia chimanimani T. Shah. EF I. Darbysh. sp. nov. Type: Zimbabwe, Manicaland, Chimanimani Mountains, at W base of (Pnt.?) 71, Linder 3990 (holotype K! [K000963156]).

http:/ /www.ipni.org/urn:lsid:ipni.org:names:77178775-1
Shrub or small tree up to $5 \mathrm{~m}$. Bark thin, pale grey (white) to brown. Branchlets grey to brown, convexly quadrangular with ridges. Leaves sessile, simple, entire, opposite except on young (or sapling) branches when ternate, blade coriaceous, obovate to oblanceolate occasionally elliptic, (19.0 -) 25.0 - $40.0 \mathrm{~mm}$ long, $10.0-25.0 \mathrm{~mm}$ wide, base attenuate, apex retuse with short mucro often with pink tinge, margins involute, sometimes with pink tinge, adaxial lamina green, glossy, glabrous, primary vein slightly impressed drying pink at base, secondary venation $6-14$ pairs, not prominent, tertiary venation conspicuous, abaxial lamina pale green, glabrous, primary vein raised, secondary veins slightly raised, tertiary vernation conspicuous. Inflorescences terminal compound cymes, total inflorescence length 21 - $48 \mathrm{~mm}$; primary inflorescence unit $0.4-1.5 \mathrm{~mm}$ long, puberulent; secondary inflorescence unit 2.1 - $4.4 \mathrm{~mm}$ long, puberulent; tertiary and quaternary inflorescence units pubescent, pink (Fig. 1). Bracts leaf-like in morphology, located on primary and secondary inflorescence axis, variable, 3.3 - $12.5 \mathrm{~mm}$ long, 1.6 $3.6 \mathrm{~mm}$ wide. Flowers 5-merous, actinomorphic, pinkish when fresh, in groups of three. Hypanthium glabrous, narrow, thinly walled, $1.5-4.7 \mathrm{~mm}$ long. Sepals highly reduced and not discernible. Petals 5, slightly thick and fleshy, spathulate, $1.2-2.25$ (- 4.0) mm long, $0.9-$ $1.4 \mathrm{~mm}$ wide, apex with short mucro, glabrous, pale yellow when dry. Scales located on the inside of petals, 0.35 - $1.2 \mathrm{~mm}$ long, $0.4-0.6 \mathrm{~mm}$ wide, densely pubescent on both surfaces. Stamens all attached along the same radius of inner hypanthium tube reaching the mouth of the flower, anthers $0.55-0.6 \mathrm{~mm}$ long. Ovary inferior, glabrous, $1.2-2.5 \mathrm{~mm}$ long, 5-locular; style puberulent, shorter than the floral tube, approx. $0.6 \mathrm{~mm}$; stigma globular. Galled flowers somewhat swollen but linear, 2.0 - 3.3 (3.9) mm long, 0.35 0.7 (1.65) $\mathrm{mm}$ wide, drying dark, without conspicuous tubercles. Drupes globose, glabrous, $\pm 6.0 \mathrm{~mm}$ in diam., 5-locular, pinkish, drying pale brown. Pericarp thinly fleshy, endocarp brown, woody, not smooth. Seeds ellipsoid to horse-shoe shaped, smooth, with spiral marking on the surface, $\pm 2.45 \mathrm{~mm}$ diam., usually only one seed per fruit due to abortion of other ovules (only immature seeds seen). Figs 1, 2 and 3.

RECOGNITION. Olinia chimanimani has previously been confused with $O$. vanguerioides as their ranges overlap. However, morphologically the two species are clearly distinct. $O$. chimanimani can be distinguished by its smaller leaf size ((19.0 -) 25.0 - $40.1 \mathrm{~mm}$ long), sessile leaf attachment, and galled flowers becoming thinly swollen when infected, without prominent tubercles, compared to O. vanguerioides which has larger (40.1 $170.0 \mathrm{~mm}$ long), petiolate leaves and flowers forming conspicuous elongate-tuberculate galls when infected. 


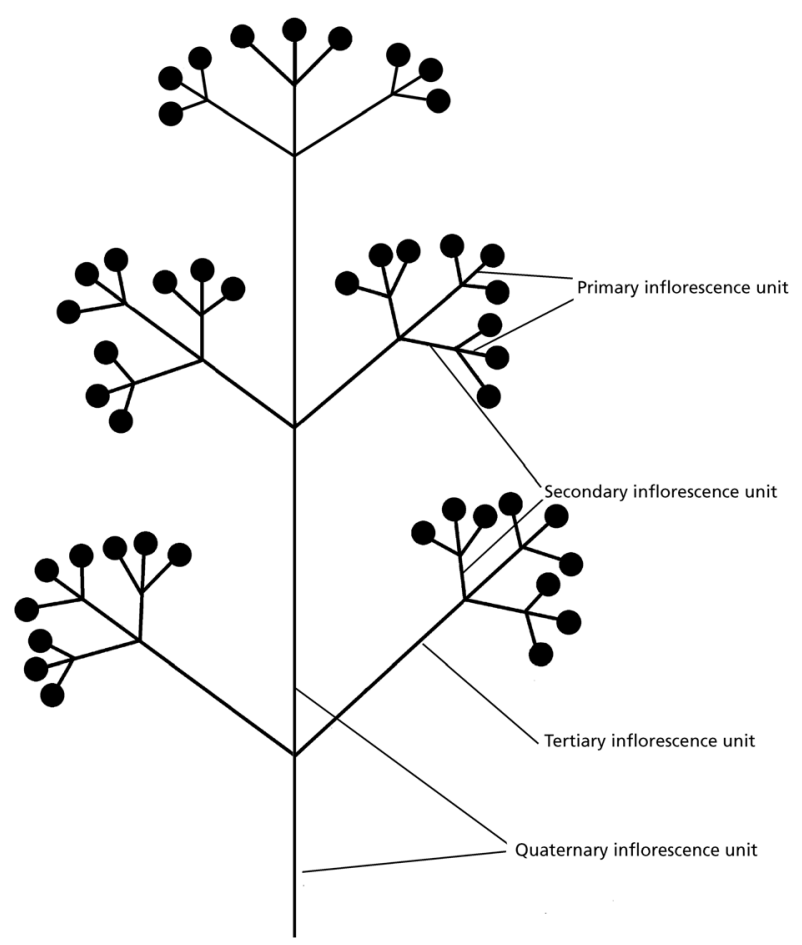

Fig. 1. Inflorescence arrangement in Olinia species, adapted from Sebola \& Balkwill (2009).

Additionally, O. chimanimani may be confused with O. huillensis A. Fern. \& R. Fern. and in particular with subsp. discolor (Mildbr.) Sebola; however, $O$. chimanimani differs from this taxon in having a leaf texture that is strictly coriaceous, smaller leaves ((19.0 -) 25.0 - $40.0 \mathrm{~mm}$ long) with a strictly sessile leaf attachment, smaller petals $(1.2-2.25(-4.0)) \mathrm{mm}$ long, $0.9-1.4 \mathrm{~mm}$ wide), glabrous inner and outer petal indumentum and strictly glabrous hypanthium indumentum (1.5 - $4.7 \mathrm{~mm}$ long). O. huillensis subsp. discolor, on the other hand, has a variable leaf texture of chartaceous to coriaceous, larger leaves (33 $77 \mathrm{~mm}$ long) with short petiole (1.0 - $5.8 \mathrm{~mm}$ long), larger petals $((1.0-) 2.0-2.9 \mathrm{~mm}$ long, $(1.2-) 1.5-$ $2.8 \mathrm{~mm}$ wide), pubescent inner petals often with stiff hairs on the margin of the inner petal, and a pubescent and larger hypanthium ((2.0) 4.5 $7.0 \mathrm{~mm}$ long). Furthermore, the two taxa differ with the gall formation of $O$. chimanimani having smaller linear galls $(0.35-0.7(-1.65) \mathrm{mm}$ wide $)$ and O. huillensis subsp. discolor has rounded, more swollen galls $(1.2-2.1 \mathrm{~mm}$ wide). Table 1 shows the diagnostic characters to differentiate the two species and O. huillensis A. Fern. \& R. Fern. s.l., a key to species is found in the Notes section.

DISTRIBUTION. Only known from Chimanimani Mountains on the border of Zimbabwe and Mozambique (Map 1).

SPECIMENS EXAMINED. MOZAMBIQUE. Chimanimani Mts, riverine above Bundi R., galled fl. Dec. 1964,
Whellan 2203 (K!); Manica, Pedza (Peza) mountain in Chimanimani, -19.74400, 33.99764, alt. 1887 m, fr., 18 April 2014, Matimele 2082 (K!, LMA); Manica, Nhamudima mountain in Chimanimani, -19.75722, 33.09328, alt. 1673 m, fl. \& fr., 21 April 2014, Matimele 2094 (K!, LMA); Chimanimani Mts, -19.75747, 33.09236, alt. 1702 m, 4 May 2016, Shah 007 (K!, LMA, SRGH); Chimanimani Mts, -19.72530, 33.09201, alt. 1786 m, 6 May 2016, Shah 013 (K!, LMA, SRGH); Chimanimani Mts, -19.725195, 33.09177, alt. 1776 m, 6 May 2016, Shah 014 (K!, SRGH). ZIMBABWE. Mt Peza, among crags, Chimanimani Mts, imm. \& galled fl., 15 Oct. 1950, Wild 3606 (K!); Manicaland, Chimanimani Mts, W base of (Pnt.?) 71, fl., 20 Nov. 1986, Linder 3990 (K! holotype).

HABITAT. This species is found growing in evergreen scrub within rocky quartzite crags and gullies and at the base of quartzite blocks on steep slopes, between 1500 - 1890 m elevation.

CONSERVATION STATUS. Olinia chimanimani is restricted to the Chimanimani Mountains on the border of central Zimbabwe and Mozambique and is currently known from eight collections, with the estimated Extent of Occurrence (EOO) and Area of Occupancy (AOO) of 40 and $28 \mathrm{~km}^{2}$ respectively (calculated using Geocat 2015). Furthermore, the total area of Chimanimani sandstone/quartzite is approximately $380 \mathrm{~km}^{2}$. Of this, the area covered by rocky quarzitic crags and associated grassland, which is the favoured habitat for this species, is approximately $270 \mathrm{~km}^{2}$; this could be taken as the maximum possible AOO for this species. The species is only known from two locations; the Zimbabwean side of the Massif which is fairly wellprotected under the Chimanimani National Park (CNP) and the Mozambique portion under the National Reserve of Chimanimani (RNC) with limited protection (Schneider et al. 2005). Additionally, although the species occurs in rocky crags, it is highly prone to burning by man, associated with the illegal artisanal mining activity present on the Mozambique side of the Chimanimani massif (Dondeyne et al. 2009). This threat has significantly declined since its peak in 2004 - 2005, as gold discoveries have lessened (Timberlake et al. 2016). However, if it were to rise again in the future, the increase of human habitation would very likely lead to a further increased frequency of fires, which would almost certainly have an impact upon the species' habitat and number of mature individuals. Severe fire damage was observed on some individuals in 2016. Furthermore, being one of the few woody species occurring at a high altitude, it will burn more easily and may be targeted as a fuel source for the miners. The species was noted to be locally rare in 2016, and with a restricted distribution and a plausible threat to its habitat, it is therefore assessed as Endangered (EN B1ab(iii, v) + B2ab(iii, v)). 


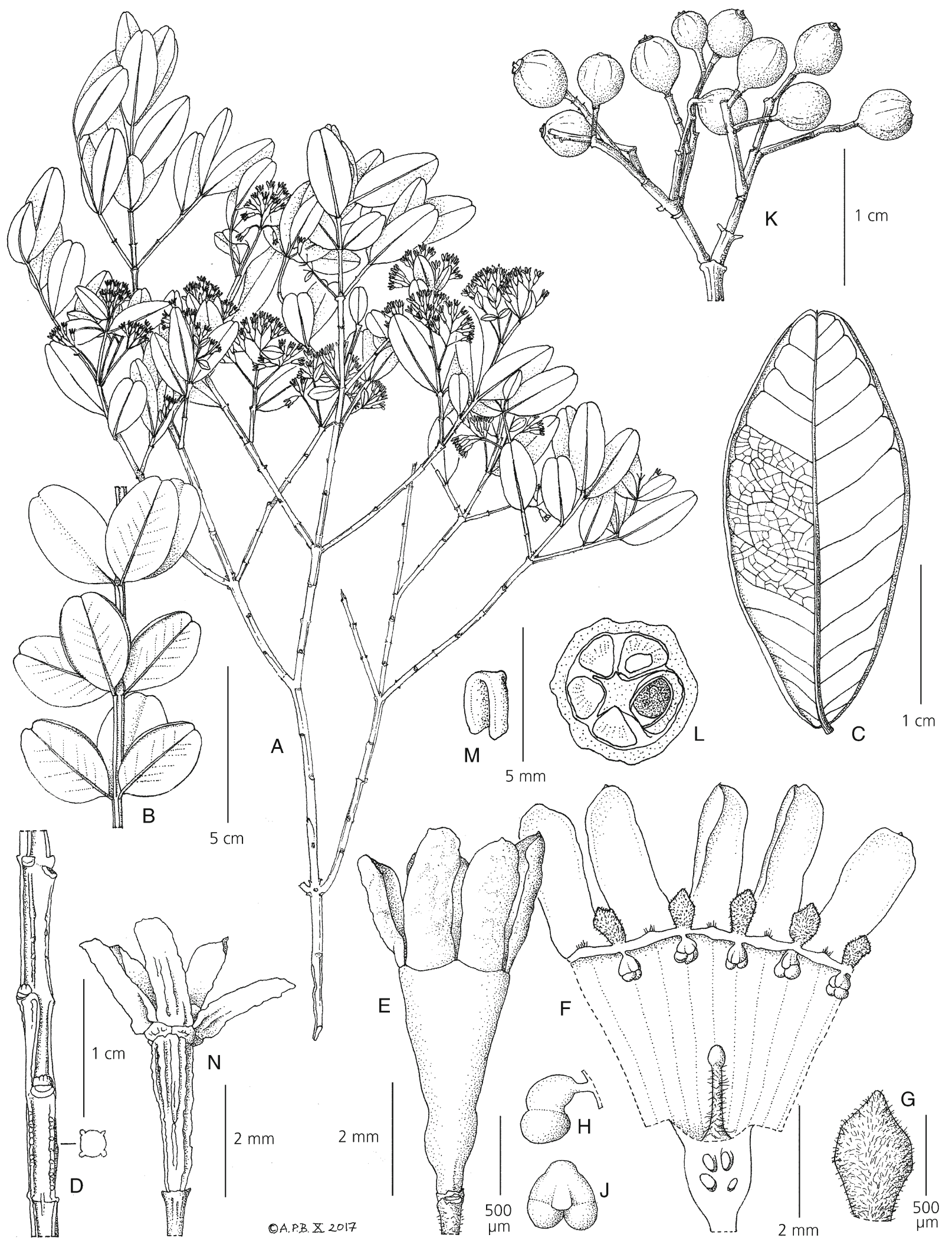

Fig. 2. A - N Olinia chimanimani: A habit; B juvenile shoot showing ternate leaf arrangement; $C$ abaxial leaf surface, conspicuous venation, margins involute; D stem with grooves; E flower; F dissected flower with stamens, style and stigma, reflexed scales, internal view; $\mathbf{G}$ enlarged scale outer surface; $\mathrm{H}$ anther, lateral view; J anther, face view; $\mathrm{K}$ infructescence; $\mathrm{L}$ fruit cross-section; $\mathrm{M}$ seed; N galled flower. A, C - J from Linder 3990, B from Shah 007, K - M from Matimele 2094, N from Whellan 2203. DRAWN BY ANDREW BROWN. 


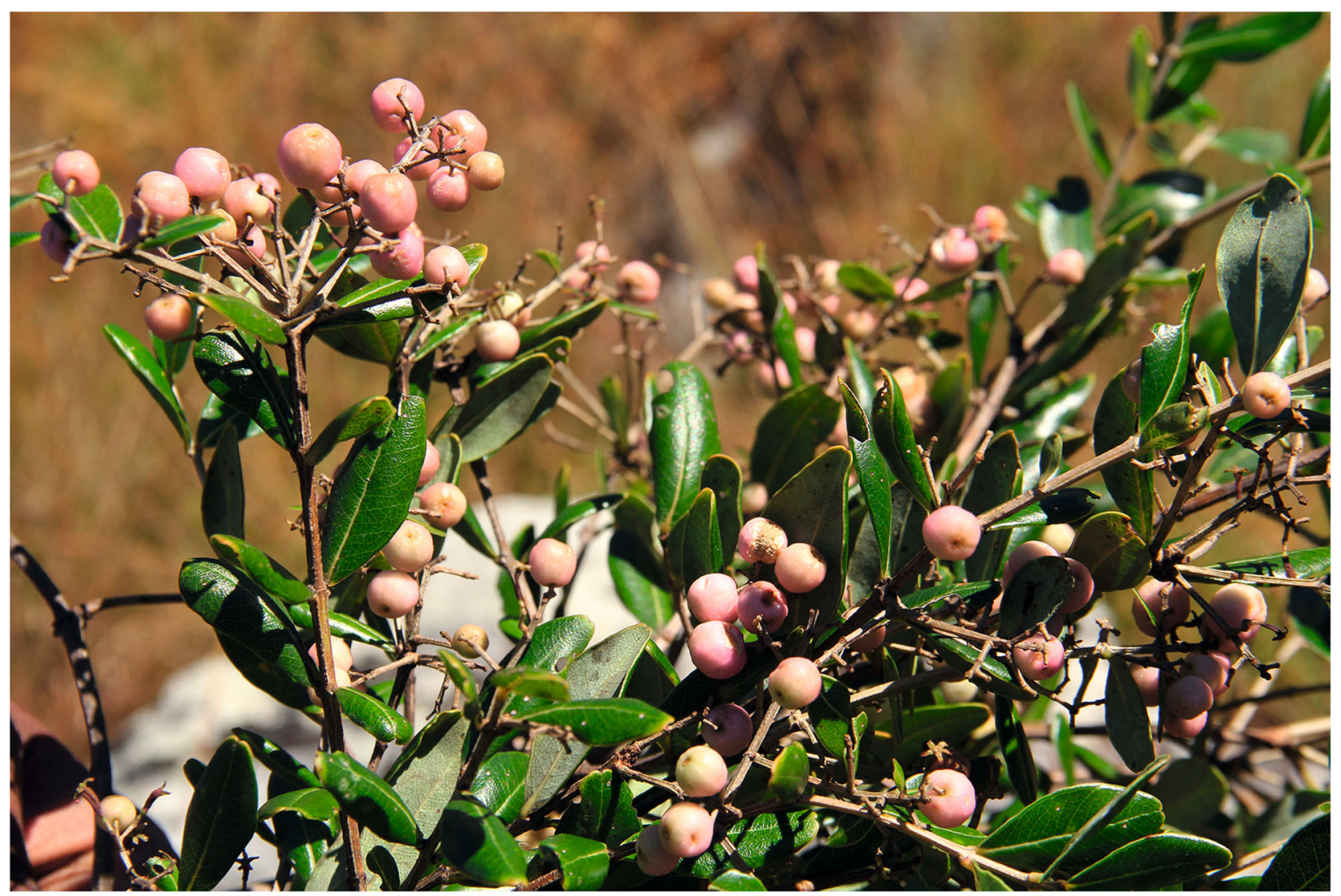

Fig. 3. Mature fruits of Olinia chimanimani photographed in the Chimanimani Mountains. PHOTO: BART WURSTEN (http:// www.mozambiqueflora.com).

ETYMOLOGY. Olinia chimanimani is named for the only mountain range on which the species occurs.

NOTES. This taxon is restricted to the higher elevations of the Chimanimani Mountains. Although once thought to be a pathological form of its close range relative, Olinia vanguerioides by Verdcourt (1978) in
Flora Zambesiaca, it is now clear that it is morphologically distinct by having significantly smaller leaves, sessile leaf attachment, smaller flowers and narrow, linear galls that form without tubercles when infected (Table 1). Additionally, Sebola \& Balkwill (2009) stated the presence of the variable taxon $O$. huillensis

Table 1. Comparison of diagnostic characters between Olinia chimanimani and two closely related species.

\begin{tabular}{|c|c|c|c|}
\hline Characters & Olinia chimanimani & Olinia vanguerioides & Olinia huilliensis s.l. \\
\hline Leaf shape & $\begin{array}{l}\text { obovate to } \\
\text { oblanceolate }\end{array}$ & elliptic & obovate (young) to elliptic \\
\hline Leaf size (mm)(length) & (19) $25-40.1$ & $40.1-170$ & (29) $33-77$ \\
\hline Leaf size (mm) (width) & $10-25$ & $20.2-44$ & $15-29$ \\
\hline Leaf texture & coriaceous & coriaceous & chartaceous (sometimes coriaceous) \\
\hline Leaf attachment & sessile & petiolate & shortly petiolate \\
\hline Leaf lamina adaxial/ abaxial & glabrous/ glabrous & $\begin{array}{l}\text { glabrous / glabrous } \\
\text { (pubescent near petiole) }\end{array}$ & glabrous / glabrous \\
\hline Petal shape & spathulate & spathulate & oblong \\
\hline Petal apex & mucronate & truncate to shortly apiculate & truncate \\
\hline Petal size (mm) (length) & $1.2-2.25(4)$ & $0.9-1.9$ & (1) $2-2.9$ \\
\hline Petal size (mm) (width) & $0.4-0.6$ & $0.5-1.1$ & $2-3.9$ \\
\hline $\begin{array}{l}\text { Petal indumentum inner/ } \\
\text { outer surface }\end{array}$ & glabrous/ glabrous & sparsely hairy (young)/ glabrous & pubescent/ glabrous \\
\hline Hypanthium surface & glabrous & glabrous & pubescent \\
\hline Gall formation & narrow, linear & elongate, tuberculate & swollen, rounded \\
\hline
\end{tabular}




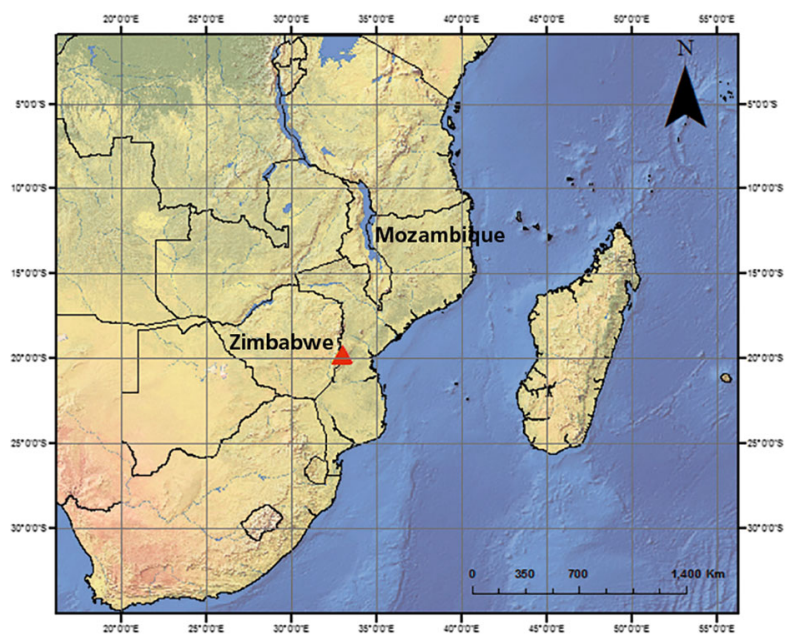

Map 1. Distribution of Olinia chimanimani in southeastern Africa. Red triangle represents the cited collections.

subsp. discolor in the Chimanimani Mountains. However, they did not cite any specimens of this taxon from the Chimanimani Mountains, Mozambique or Zimbabwe nor gave any indication of this on the distribution map for subsp. discolor. It is possible that the authors included this new taxon within the limits of $O$. huillensis subsp. discolor, although the specimens of the new taxon that were loaned to Sebola $(\mathrm{J})$ at the time of that revision were not annotated as such. However, when closely examined, O. chimanimani always has a strictly sessile leaf attachment, glabrous inner and outer petals, a glabrous and smaller hypanthium and linear gall formation, characters that differ from $O$. huillensis including subsp. discolor. Table 1 shows the morphological character differences between $O$. chimanimani, O. vanguerioides and $O$. huillensis s.l. because the delimitation of O. huillensis subsp. discolor must necessarily fit within the larger taxonomic concept of O. huillensis s.l. Therefore, the subspecies is not included in the table in order to compare taxa at the species level. With recent developments in molecular analysis it would be desirable to carry out Next Generation Sequencing (NGS) to more accurately resolve the species limits within this genus. However, at present, morphological analysis provides the best conclusions for species delimitation. A modified key to the species of Olinia sect. Rochetiana is presented below to help with the identification of the closely related taxa, a key to the infraspecific taxa of $O$. huillensis s.l. is available in Sebola \& Balkwill (2013).

\section{Key to taxa within Olinia sect. Rochetiana (adapted from Sebola \& Balkwill 2009)}

1. Leaf lamina narrowly elliptic, 40.1 - $170 \times 20.2-44 \mathrm{~mm}$; petioles puberulent, 6 - 9 mm long; galled flowers

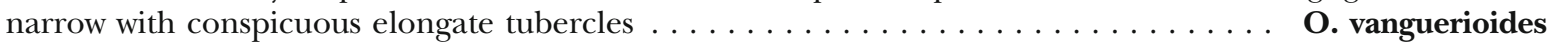

Leaf lamina obovate to oblanceolate, (19.0) $25-40.1 \times 10-25 \mathrm{~mm}$; leaves sessile or petioles $<6 \mathrm{~mm}$ long; galled flowers either swollen or if narrow and linear then lacking elongate tubercles . . . . . . . . . . . 2

2. Leaf lamina with conspicuous reticulate venation on both surfaces; leaves strictly sessile; petals $0.35-1.2 \times 0.4-$ $0.6 \mathrm{~mm}$, glabrous on both sides; hypanthium glabrous; galled flowers narrow and linear . O. chimanimani

Leaf lamina with conspicuous reticulate venation on undersurface only; leaves shortly petiolate; petals $3-5 \times 1-2 \mathrm{~mm}$, pubescent on the inside or at least on petal margins; galled flowers swollen $\ldots \ldots \ldots \ldots$

3. Leaves somewhat chartaceous; up to 7 inflorescence units along inflorescence axes . . . . . . O. huillensis

Leaves coriaceous; between $9-11$ inflorescence units along inflorescence axes . . . . . . . . . . . 4

4. Leaf lamina discolorous, broader than long; internodes on terminal branches longer than inflorescence axes $\ldots \ldots \ldots \ldots \ldots \ldots \ldots \ldots \ldots \ldots \ldots \ldots \ldots \ldots \ldots$ ruandensis

Leaf lamina concolorous, longer than broad; internodes on terminal branches shorter or equal to inflorescence

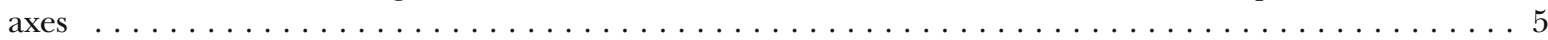

5. Petals 5 on lateral flowers; scales shorter than $1 \mathrm{~mm}$, rarely sealing the hypanthium opening/ throat . . . O. rochetiana Petals 4 on lateral flowers; scales longer than $1 \mathrm{~mm}$, often sealing the hypanthium opening/ throat ....

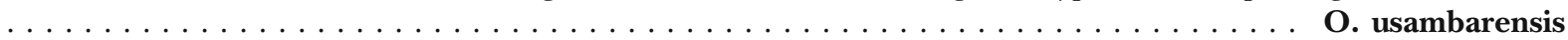

\section{Acknowledgements}

Research on the flora of the high Chimanimani Mountains and its endemic species was supported by the Critical Ecosystems Partnership Fund Grant 63512: "In from the cold: providing the knowledge base for comprehensive biodiversity conservation in the Chimanimani Mountains, Mozambique; botanical survey component" completed in 2016; see http://www.cepf.net/
SiteCollectionDocuments/eastern_afromontane/ FinalReport_RBC_ChimanimaniMountains.pdf. Toral Shah's participation in the field expedition to the Mozambique Chimanimani in May 2016 was supported by the Bentham-Moxon Trust. Joanna Osborne, Jonathan Timberlake, Anthony Mapaura, Aurelio Banze, Daglasse Muassinar, João Massunde, Bart Wursten, Petra Ballings and all other participants 
are thanked for their collaboration in these field expeditions. We are grateful to the Micaia Foundation for their support and collaboration on this project and their logistical field support. We also thank Andrew Brown for the excellent illustration of the new species and Bart Wursten for allowing us to use the photograph of the new species.

Open Access This article is distributed under the terms of the Creative Commons Attribution 4.0 International License (http://creativecommons.org/ licenses/by/4.0/), which permits unrestricted use, distribution, and reproduction in any medium, provided you give appropriate credit to the original author(s) and the source, provide a link to the Creative Commons license, and indicate if changes were made.

\section{References}

APG IV (2016). An update of the angiosperm Phylogeny Group classification for the orders and families of flowering plants: APG IV. Bot. J. Linn. Soc. 181: 1 - 20.

Beentje, H. (2010). The Kew Plant Glossary. An illustrated dictionary of plants terms. Royal Botanic Gardens, Kew.

BirdLife International (2012). Ecosystem Profile: Eastern Afromontane Biodiversity Hotspot. Prepared for the Critical Ecosystem Partnership Fund. Available at: http://www.cepf.net/sites / default/files / eastern_afromontane_ecosystem_profile_final.pdf. Accessed 4 June 2018.

Cheek, M., Chipanga, H. \& Darbyshire, I. (in press, 2018). Empogona jenniferae (Rubiaceae-Coffeeae), a new Critically Endangered species endemic to the quartzitic slopes of Mt. Chimanimani (Mozambique \& Zimbabwe). Blumea.

Clark, V. R., Barker, N. P. \& Mucina, L. (2011). The Great Escarpment of southern Africa: a new frontier for biodiversity exploration. Biodivers. Conserv. 20: 2543 - 2561.

Dondeyne, S., Ndunguru, E., Rafael, P. \& Bannerman, J. (2009). Artisanal mining in central Mozambique: policy and environmental issues of concern. Resour. Policy 34: $45-50$.
GeoCAT (2015). Geospatial Conservation Assessment Tool. http:/ /geocat.kew.org. Accessed June 2016.

Heywood, V. H., Brummitt, R. K., Culham, A. \& Seberg, O. (2007). Flowering Plant Families of the World. Royal Botanic Gardens, Kew.

IUCN (2012). IUCN Red List Categories and Criteria: Version 3.1. Second Edition. IUCN Species Survival Commission. IUCN, Gland \& Cambridge.

Jussieu, de M. (1846). Olinia rochetiana In: Compt. Rend. Hebd. Séances Acad. Sci. 22: 812

McNeill, J., Barrie, F. R., Buck, W. R., Demoulin, V., Greuter, W., Hawksworth, D. L., Herendeen, P. S., Knapp, S., Marhold, K., Prado, J., Prud'homme Van Reine, W. F., Smith, G. F., Wiersema, J. H. \& Turland, N. J. (eds) (2012). International Code of Nomenclature for algae, fungi, and plants (Melbourne Code). Regnum Veg. 154. Koeltz Scientific Books. http://www.iapt-taxon.org/nomen/ main.php

Schneider, M., Buramuge, V., Aliasse, L. \& Serfontein, F. (2005). Checklist and Centres of Vertebrate Diversity in Mozambique. Forestry Department (DEF), Eduardo Mondlane University, Maputo.

Sebola, R. J. \& Balkwill, K. (2009). Numerical phenetic analysis of Olinia rochetiana sensu lato (Oliniaceae). Kew Bull. 64: 95 - 121.

\& _ (2013). A monographic study of the Oliniaceae. Kew Bull. 68: 419 - 456.

Timberlake, J. R., Darbyshire, I., Wursten, B., HadjHammou, J., Ballings, P., Mapaura, A., Matimele, H., Banze, A., Chipanga, H., Muassinar, D., Massunde, M., Chelene, I., Osborne, J. \& Shah, T. (2016). Chimanimani Mountains: Botany and Conservation. Report produced under CEPF Grant 63512. Royal Botanic Gardens, Kew.

Verdcourt, B. (1978). Oliniaceae. In: E. Launert (ed.), Flora Zambesiaca 4: 323 - 327. Crown Agents for Oversea Governments and Administrations, London.

Wild, H. (1964). The Endemic Species of the Chimanimani Mountains and their Significance. Kirkia 4: 125 - 157.

Wursten, B., Timberlake, J. \& Darbyshire, I. (2017). The Chimanimani Mountains: an updated checklist. Kirkia 19: $70-100$. 